\title{
VULNERABILITY MAPPING IN THE RECHARGE AREA OF THE KORENTAN SPRING, SLOVENIA
}

\section{KARTIRANJE RANLJIVOSTI V ZALEDJU IZVIRA KORENTAN, SLOVENIJA}

\author{
METKA PETRIČ $^{1} \&$ STANKA ŠEBELA ${ }^{1}$
}

${ }^{1}$ Karst Research Institute ZRC SAZU, Titov trg 2, SI-6230 Postojna, Slovenia, e-mail: petric@zrc-sazu.si, sebela@zrc-sazu.si 


\section{Metka Petrič \& Stanka Šebela: Vulnerability mapping in the recharge area of the Korentan spring, Slovenia}

Karst aquifers are very vulnerable to pollution due to well developed system of karst channels and fissures which enable fast groundwater flow and also fast transport of pollutants. An expert bases for their protection are vulnerability maps. Different methods for the construction of these maps were developed, and to assess the vulnerability of the recharge area of the Korentan spring near Postojna the EPIK method was used. In this method, which was many times successfully tested on karst, the degree of vulnerabilty is defined on the basis of four parameters: developement of the epikarst, effectiveness of the protective cover, infiltration conditions, and development of the karst network. For the assessment of individual parameters different research methods were used, such as detailed structural-lithological and geomorphological mapping, and combined analysis of hydraulic and physico-chemical responses of the spring to recharge events. Final result is the vulnerability map, which defines the areas of very high, high and moderate vulnerability within the recharge area of the Korentan spring and can be used to set up the protection zones.

Key words: vulnerability, structural-lithological mapping, discharge, specific electrical conductivity, Korentan, Slovenia.

\section{Izvleček}

UDK: 556:3:659.2:004(497.4)

\section{Metka Petrič \& Stanka Šebela: Kartiranje ranljivosti v zaledju izvira Korentan, Slovenija}

Zaradi dobro razvitega sistema kraških kanalov in razpok, ki omogoča hiter tok podzemne vode in tudi hiter prenos škodljivih snovi, so kraški vodonosniki zelo ranljivi za onesnaženje. Osnovo za njihovo ustrezno varovanje predstavljajo karte ranljivosti. Za izdelavo teh kart so bile razvite različne metode, pri oceni ranljivosti zaledja izvira Korentan pri Postojni pa smo uporabili metodo EPIK, ki je bila že večkrat uspešno preizkušena na krasu in stopnjo ranljivosti določa v odvisnosti od štirih parametrov: razvitosti epikrasa, učinkovitosti varovalnega pokrova, pogojev infiltracije in razvitosti kraške mreže. Za oceno posameznih parametrov smo uporabili različne raziskovalne metode kot so podrobno strukturno-litološko in geomorfološko kartiranje ter vzporedna analiza hidravličnih in fizikalno-kemičnih odzivov izvira na padavinske dogodke. Izdelana karta ranljivosti opredeljuje območja zelo velike, velike in zmerne ranljivosti znotraj zaledja izvira Korentana in jo lahko uporabimo kot osnovo za omejitev varstvenih pasov.

Ključne besede: ranljivost, strukturno-litološko kartiranje, pretok, specifična električna prevodnost, Korentan, Slovenija. 


\section{INTRODUCTION}

The Korentan spring is the main outflow from the karst aquifer of the Orehek area. Until 1972 it was included in the water supply system of the Postojna area, and recently its reactivation as a reserve source has been discussed again. Its recharge area has been protected by a decree since 1998 . Protection zones and measures were defined based on the report "Researches of the karst springs in Malni near Postojna and of the recharge areas of the water resources in the commune of Postojna" prepared in 1987 (Habič et al. 1987). But in the everyday practice of regional planning the need to update this expert's basis has become evident. The study with the main goal to review the existing guidelines for protection was initiated and financed by the Municipality of Postojna and performed by the Karst Research Institute ZRC SAZU. The research was additionally supported by the Ministry of Education, Science and Sport of the Republic of Slovenia.

As a basis for the new determination of the water protection zones an intrinsic vulnerability map of the karst aquifer in the recharge zone of the Korentan spring has been prepared with the use of the EPIK method (Doerfliger et al. 1999). It is one from the group of parametric methods, which was specially created for use in karst regions. As the most representative to evaluate the vulnerability of groundwater four parameters are defined: epikarst, protective cover, infiltration conditions, and degree of karstic network. To assess these parameters as precise as possible different research methods were used. The emphasis was on detailed structural-lithological and geomorphological field mapping in the recharge area, as well as on the monitoring of discharges and physico-chemical parameters of the Korentan spring.

\section{CHARACTERISTICS OF THE RECHARGE AREA}

\section{Geological conditions}

The so-called Orehek karst covers the area of around $9 \mathrm{~km}^{2}$ (Fig. 1). With the altitudes of up to $725 \mathrm{~m}$ it has a shape of slightly uplifted ridge above the surrounding villages of Hruševje, Orehek, Rakulik, and Sajevče at the altitudes from $545 \mathrm{~m}$ to $600 \mathrm{~m}$. The mean altitude of the karst area is around $620 \mathrm{~m}$.

According to basic geological map sheet Postojna (Buser et al. 1967) the Orehek karst is composed of Upper Cretaceous limestone $\mathrm{K}_{2}{ }^{2,3}$, which is thrusted over Eocene flysch in the SW part of the studied area. Limestone is presented by grey rudist limestone with weakly determined Radiolite fauna and untypical microfauna. In the tectonic sense the Orehek karst is part of the JavornikiSnežnik thrust sheet unit (Pleničar 1970). According to Placer $(1981,1999)$ it belongs to Snežnik thrust sheet, which is thrusted over the Komen thrust sheet.

The geological map of Orehek karst compiled by Gospodarič et al. (1970) is different than basic geological map sheet Postojna (Buser et al. 1967). Upper Cretaceous partly granulated and brecciated limestones with rudists were determined around Prestranek castle and also in the narrow belt near Orehek, south from Hruševje and north from Sajevče and Rakulik. Middle part of the area is built of Paleogene limestones, which are presented by dark limestones of Liburnian formation with foraminifera Rhipidionina liburnica Stache and Rhapidionina liburnica Stache and with snails Stomatopsis sp. and Cosinia cf. For those limestones the finely grained structure and well developed bedding planes are characteristic. In some parts limestone alterates into a shally limestone contain- 
ing some cherts.

NE from Sajevče the Cretaceous and Liburnian limestones are folded into the anticline in Dinaric orientation, that sinks towards NW. Between Orehek and Rakulik the second almost paralel anticline takes place in Liburnian limestones (Fig. 2).

The Liburnian formation consists of lithological and facies similar beds from the same evolution cycle (from Maastrichtian-upper part of Upper Cretaceous to Thanetian-lower part of Lower Paleogene). According to Jurkovšek et al. (1996) the Liburnian formation (d=250-400 m) represents the beds that show the characteristics of marine, brackish and freshwater sedimentation environment where different structural types of limestone alterate one to another in horizontal and vertical direction. The origin of Liburnian formation coincide with Laramian tectonic phase. That is also the cause for heterogeneity and rapid changes of sedimentation conditions.

The Liburnian formation is concordant over Senonian limestone north from Prestranek and in tectonical contact north from Sajevče (Gospodarič et al. 1970).

The swallow holes of Orehovške ponikve are disposed along the thrust of limestone over flysch that is where the streams coming from flysch ravines are sinking into the Orehek karst. Gospodaric (1989) calls this structure Rakulik thrust. The NE edge of Orehek karst is represented by tectonic contact between Senonian and Paleogene limestones and with flysch of Postojna valley. Taking into account the studies of Gospodarič et al. (1979) we have to consider that the Orehek karst is not covering the impermeable flysch base, but is only partially thrusted over flysch and encircled by it. Thrusted part of Orehek karst is not tore off the Cretaceous and Paleogene autochthonous base.

\section{Hydrogeological characteristics}

The main outflow from the karst aquifer is the Korentan spring (Fig. 1). It is situated at the altitude $540 \mathrm{~m}$ at the northern border of the carbonate massif, on the contact with the very low permeable flysch in the surroundings. According to their hydrogeological character the carbonate rocks are characterised as a well permeable karst aquifer, and the surrounding flysch as a hydrogeological barrier.

In the broader Orehek area 11 springs were registered, but only 3 of them are located at the contact limestone-flysch and drain the karst aquifer (Schulte 1994). Besides the Korentan spring in this group are also two intermittent karst springs Mrzla jama and Poliček, which are only active at very high waters when their discharges reach up to several tens of litres per second. Water from both springs forms small brooks, which are flowing towards east into the Pivka river.

At the southern border surface streams on flysch sink into the ponors at the contact with limestone, and recharge the karst aquifer. These sinking streams drain a flysch area of around $1.5 \mathrm{~km}^{2}$. South-eastern from Rakulik the Črmelice ponor is located, and then further towards south-east the Orehovške ponikve with several sinking points (Fig. 1).

\section{Outlining the recharge area of the Korentan spring}

The outlining of boundaries of the recharge area of the Korentan spring was based upon an understanding of the geological structure, calculation of water balance, and upon results obtained by previously performed tracing tests. According to the geological map the border of the karst aquifer was defined along the contact between limestone and surrounding flysch. Then in the next phase the watershed between the Korentan spring and the two other karst springs in the area was 
set. First the extent of the recharge area of the Korentan spring was assessed. The calculation of water balance was based upon the premise that within a period of one hydrological year the overall runoff from the karst system is equal to the amount of water, which has in the same period fallen on the entire recharge area in the form of precipitation, but reduced for that part of water that is sent back into the atmosphere by evapotranspiration. As the discharges of the Korentan spring have been regularly measured only since June 2003, the data for the hydrological year 2003/2004 were used in the estimation. The mean discharge for this period is $0.2 \mathrm{~m}^{3} / \mathrm{s}$, and the amount of precipitation measured at the nearby Postojna meteorological station $1618 \mathrm{~mm}$. For the calculation of daily values

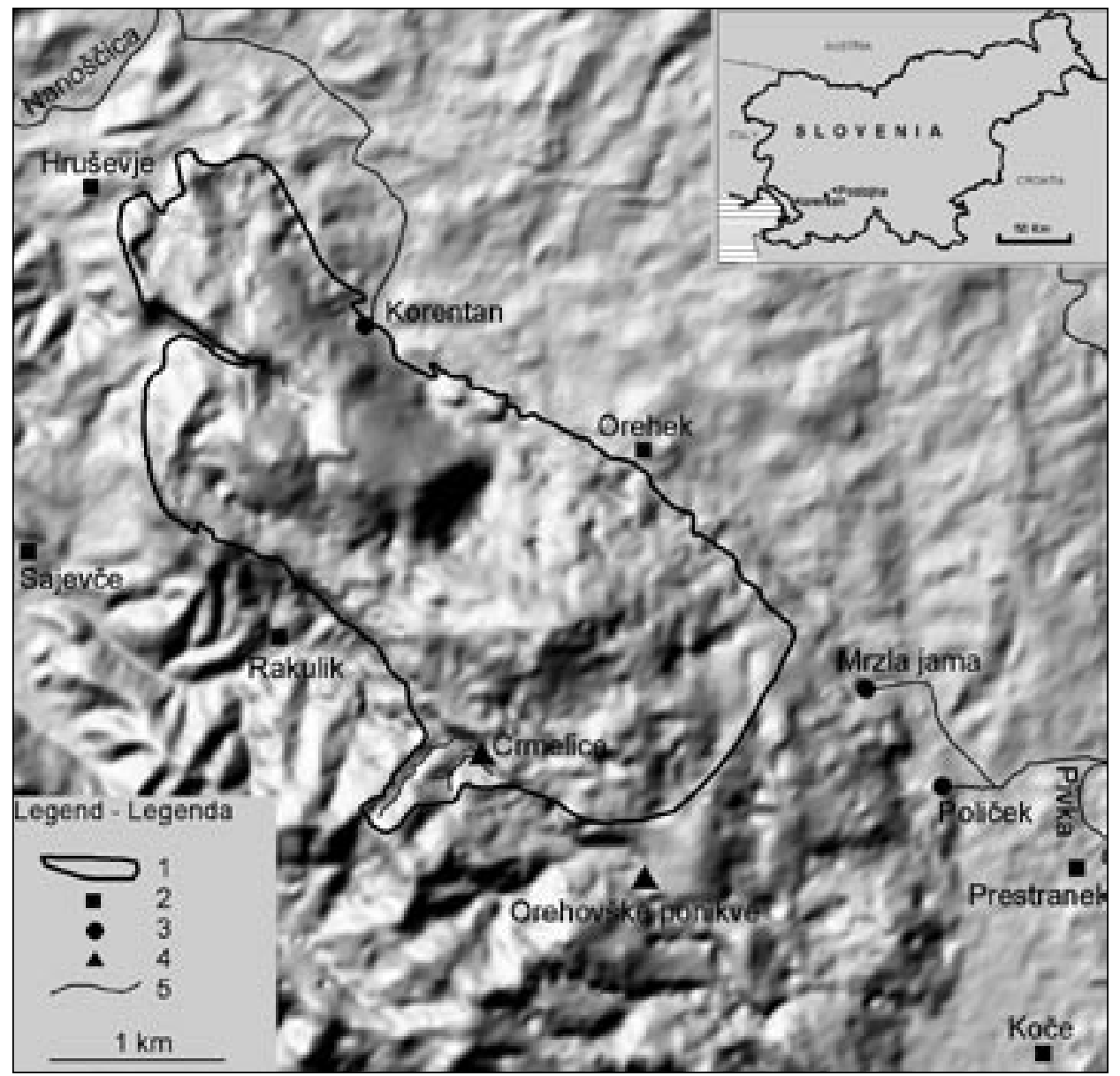

Fig. 1: Relief map of the Orehek karst (Legend: 1. Border of the recharge area, 2. Settlement, 3. Karst spring, 4. Ponor, 5. Surface stream).

Sl. 1: Reliefna karta Orehovškega krasa (Legenda: 1. meja zaledja, 2. naselje, 3. kraški izvir, 4. ponor, 5. površinski tok). 
of evapotranspiration the modified Penman equation was used (Shaw 1994) and the total amount of evapotranspiration in the observed period of one hydrological year was assessed to $592 \mathrm{~mm}$. The difference between the values of precipitation and evapotranspiration represents the amount of water that infiltrates into aquifer during this interval. The comparison of this value with the average discharge of the Korentan spring, however, enabled us to evaluate the size of the recharge area at approximately $5.8 \mathrm{~km}^{2}$.

The first tracer test was performed in 1967 (Gospodarič et al. 1970). The sinking stream in the Orehovške ponikve was traced at high waters and the underground water connection with the Poliček spring near Prestranek was proved (Fig. 1). As the altitude of the Korentan spring is above the outflow level of the Poliček spring it was inferred that also at low waters the eastern part of the studied karst aquifer is drained underground towards the Pivka river.

In the second tracer test uranine was injected in the Črmelice sinking stream. All nearby springs were sampled, but the tracer was detected only in the Korentan spring. The recovery rate of tracer was estimated to $71 \%$ (Schulte 1994).

Based on presented results the south-eastern border of the recharge area of the Korentan spring was set between the two mentioned sinking points (Fig. 1). Also the flysch area, which drains towards the Črmelice sinking stream is included. Watershed with nearby surface streams is set along the orographic borders and the part of recharge area on flysch covers $0.2 \mathrm{~km}^{2}$. The rest with the area of $5.6 \mathrm{~km}^{2}$ is karstic.

\section{Geomorphological characteristics}

Inside the recharge area the limestone is well karstified with typical surface and underground karst features. The most common relief form are dolines. Their density and distribution differ from one part to the other, but mostly they are distributed along the main tectonic zones (Fig. 2). The average density within the catchment is around 60 dolines per square kilometer.

Around 40 karst caves located inside the catchment are registered in the Slovene Cave Cadastre (Fig. 2). They are mostly small caves or shafts, but some are also more than 100 meters long.

Ponors are characteristic feature for the contact flysch-limestone at the southern border, but only the Črmelice sinking stream belongs to the recharge area of the Korentan spring (Fig. 2). It sinks at the altitude $620 \mathrm{~m}$ below a $10 \mathrm{~m}$ high rock wall. During low waters its discharge is less than 1 1/s, and can reach at high waters several litres per second (Gospodarič et al. 1970). A small sinking stream appears also at the location Sv. Barbara in the western part of the catchment, where waters are collected on a flysch surface and sink into a ponor only after several tens of meters of surface flow (Fig. 2).

At the Korentan spring water outflows through several fissures in the $50 \mathrm{~m}$ wide spring area. One of the fissures was widened into a well, in which three pumps were installed in the time of active use of the spring for water supply. Water from these separate outflows is collected into an artificial channel below the road Hruševje-Orehek, and then flows on the surface as the Korentan brook towards the Nanoščica brook, which is a tributary of the Pivka river.

\section{DETAILED STRUCTURAL-LITHOLOGICAL MAPPING}

The detailed structural lithogical field mapping of Orehek karst was performed in the scale of 1: 5.000 using the method of Čar (1982). The tectonic deformations connected with folding and thrust- 
ing as thrusts and anticlines were detected on the studied area (Fig. 2). The tectonic and lithological contacts between Eocene flysch and carbonate rocks were determined as well. The interpretations regarding thrust or lithological contacts between flysch and limestones are different (Gospodarič et al. 1970, Gospodarič 1989, Pleničar 1970, Schulte 1994). All authors are interpreting the W and SW edge of Orehek karst as thrust contact where limestone is thrusted over flysch between Hruševje, Rakulik and Koče. Regarding the basic geological map sheet Postojna (Buser et al. 1967) the same thrust fault is continuing towards SE, E from Koče. Gospodarič (1989) named it Rakulik thrust.

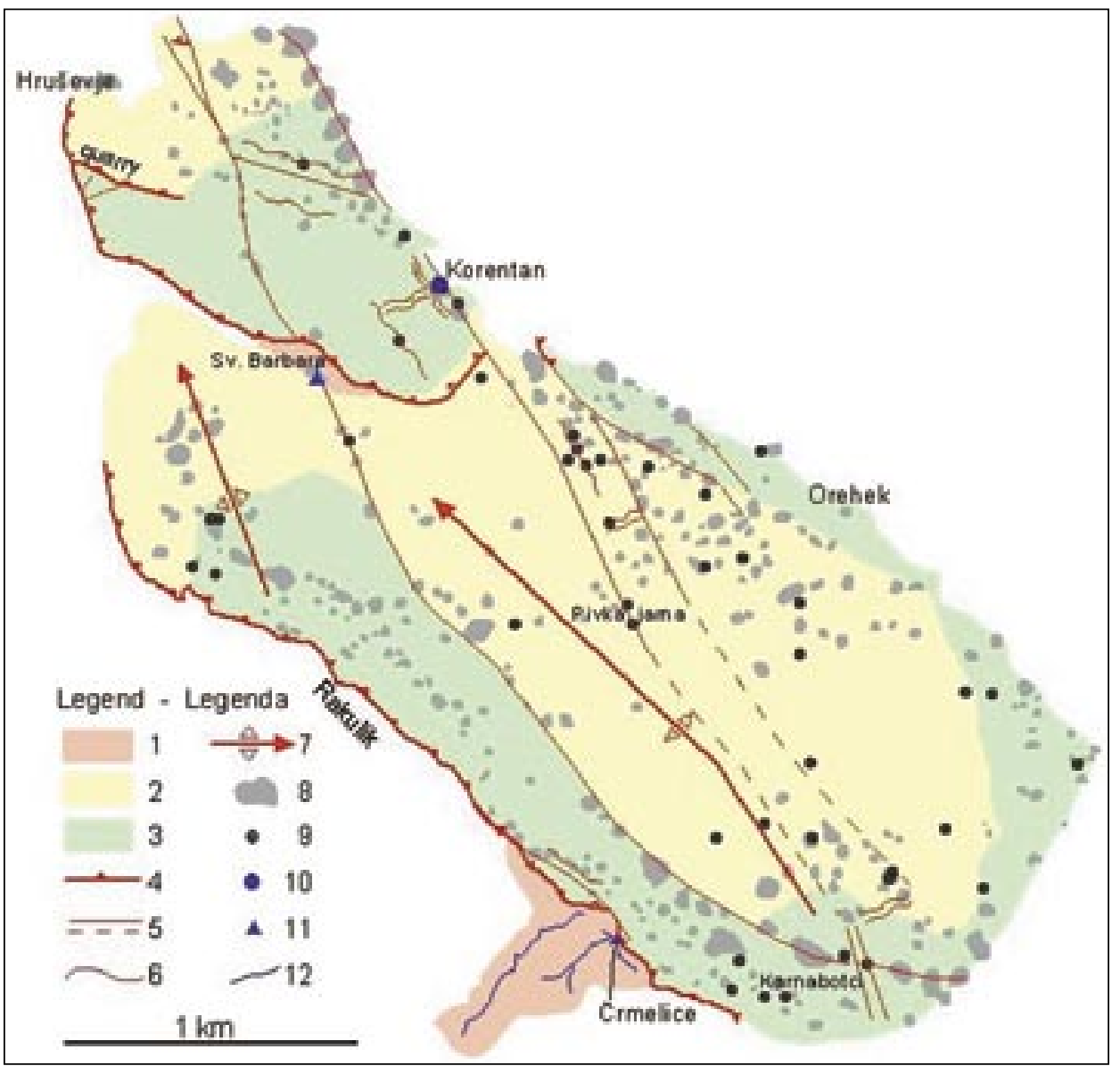

Fig. 2: Geological map (Legend: 1. Eocene flysch, 2. Paleogene limestone, 3. Cretaceous limestone, 4. Thrust, 5. Visible and covered fault, 6. Fissured zone, 7. Anticlinal axis, 8. Doline, 9. Karst cave, 10. Spring, 11. Ponor, 12. Surface stream).

Sl. 2: Geološka karta (Legenda: 1. eocenski fliš, 2. paleogenski apnenec, 3. kredni apnenec, 4. nariv, 5. viden in pokrit prelom, 6. razpoklinska cona, 7. os antiklinale, 8. vrtača, 9. kraška jama, 10. izvir, 11. ponor, 12. površinski tok). 
With field studies we measured the geological elements along the Rakulik thrust (55/50 and 60/30), and in flysch below the thrust where the elements are 30/30, 30/40 and 10/40.

The $\mathrm{N}$ contact of Orehek karst between limestone and flysch is differently interpreted. Gospodarič et al. (1970) detected the erosional border on the lithological contact flysch-limestone between Korentan and Orehek. Further NW from Korentan towards Hruševje the contact is tectonic (Gospodarič et al. 1970), but not thrust contact as is described by Schulte (1994). With advanced studies Gospodarič (1989) determined the N edge of Orehek karst as fault zone (Orehek fault) between flysch and limestone.

The geological borders between Upper Cretaceous and Paleogene limestones are on the map of Gospodarič et al. (1970) shown as tectonic or as lithological-concordant contacts. For Schulte (1994) most of the Upper Cretaceous-Paleogene limestone borders are thrust contacts. The data of our detailed structural lithological field mapping are closer to the interpretations of Gospodarič et al. (1970) and Gospodarič (1989).

With our detailed structural lithological field mapping we confirmed the position of two anticlines what is in concordance with the results of Gospodarič et al. (1970) and Schulte (1994).

Between Rakulik and Črmelice on the southern edge of Orehek karst we detected the stronger dinaric oriented fault zone along the Rakulik thrust. North from Črmelice the fault zone dips towards SW for $80-85^{\circ}$, at the swallow hole area of Črmelice the fault zone turns its dip direction towards NE (60/80). The Rakulik thrust fault between limestone and flysch is at least on one place displaced by dinaric oriented fault zone. This shows that the thrust is older than the fault zone.

Very well was detected also the thrust between limestone of Liburnian formation over Upper Cretaceous limestone in Hruševje quarry. Towards the E the thrust is cut and displaced by dinaric oriented fault zone 70/40 that according to Schulte (1994) contains thrust characteristics. Our data show that the same fault has horizontal movement, left movement. The fault can be traced in the area of Sv. Barbara, where crosses the tectonic half-window of Eocene flysch (Schulte 1994). Towards SE the fault forms the contact between Upper Cretaceous limestone and Liburnian limestone. In the area north from Karnabotci the fault changes the direction, from dinaric orientation passes on to almost E-W direction $\left(10-20^{\circ}\right)$. In that part the fault is cut by two paralel dinaric oriented faults (250/70 and 80).

The structural geological data of the NE edge of Orehek karst obtained by our field mapping are more like maps of Gospodarič et al. (1970) and Gospodarič (1989) than like several thrust contacts between lithological units as was described by Schulte (1994). NW from the Korentan spring the contact between flysch and limestone is tectonic. Gospodarič (1989) named this Orehek fault and determined it further on along the flysch-limestone contact SE from Korentan spring in the direction towards Prestranek. According to our field data the same fault continues south from Korentan spring, runs through the shaft Pivka jama and is well visible again north from Karnabotci. Our field data support the idea that NW part from Orehek (what is SE part from Korentan spring) represents erosional border between flysch and limestone and tectonic contact between Upper Cretaceous limestone and Liburnian formation. The karst between Orehek and Rakulik is folded into two almost parallel anticlines and covered with dinaric oriented faults and fissured and broken zones of dinaric and cross-dinaric orientation.

According to Čar (1982) the fissured and broken zones are well permeable for water percolation and water transport. The anticline crest in the area of Postojnska jama is deformed with wide fissured to broken zones (Šebela 1998) as is also the case in Orehek karst. 


\section{SPRING RESPONSE TO PRECIPITATION EVENTS}

\section{Measurements and data collection}

The gauging station at the Korentan spring was first put into operation from September 1993 to February 1994 (Schulte 1994). In this period discharges from $20 \mathrm{l} / \mathrm{s}$ to $2 \mathrm{~m}^{3} / \mathrm{s}$ were measured.

At the same location the equipment for the measurement of discharges was installed in June 2003. The water level is measured in the well by the use of the flowmeter ISCO 750 Area-Velocity Module. The time interval of data recording is 15 minutes. Additional to this, the discharges of the

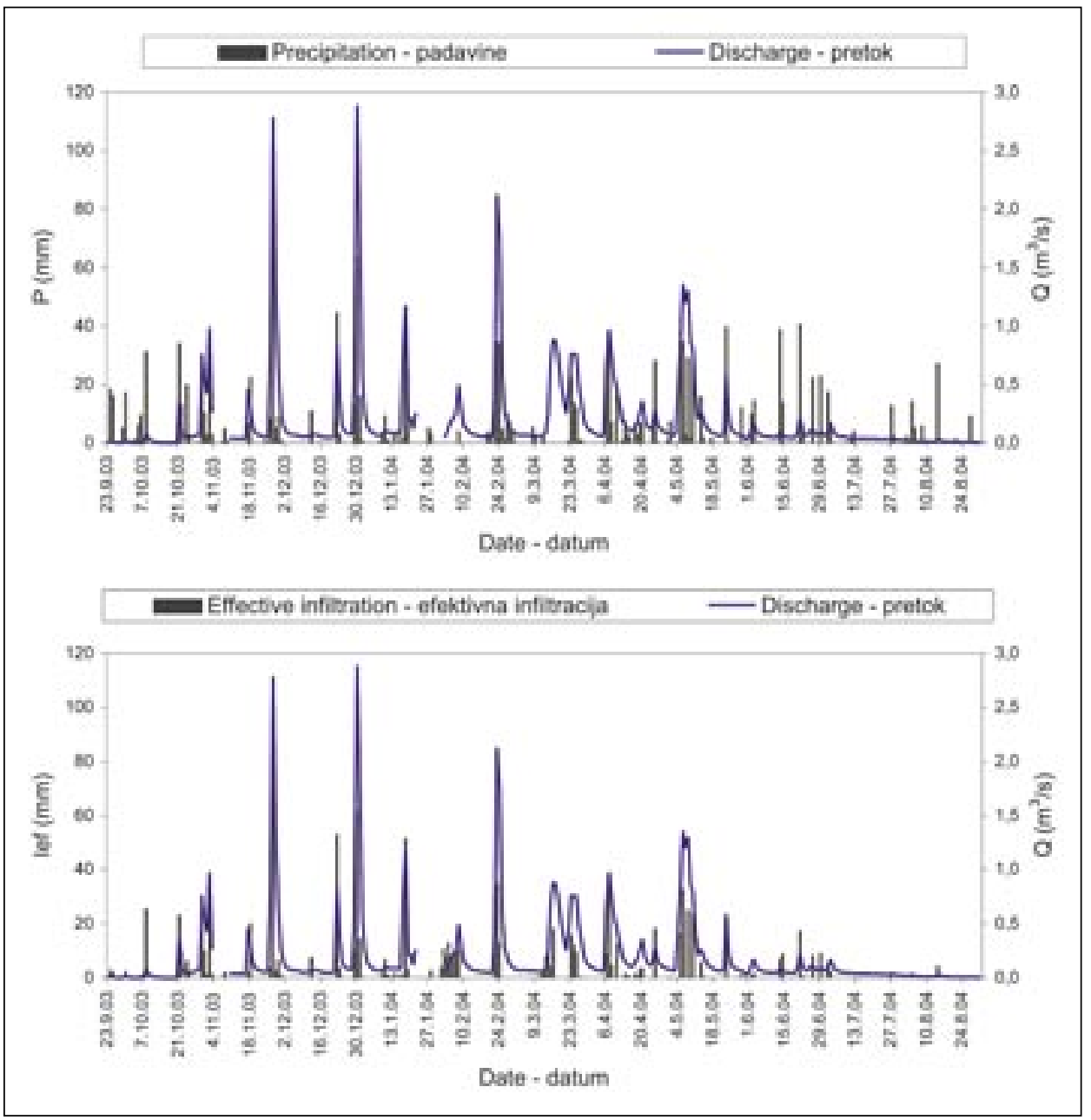

Fig. 3: Hydrograph of the Korentan spring for one hydrological year, comparison with precipitation and effective infiltration.

Sl. 3: Hidrogram izvira za eno hidrološko leto, primerjava s padavinami in efektivno infiltracijo. 
spring are measured in the artificial channel below the bridge occasionally by the use of the current meter OTT C20. Based on the correlation between both sets of data the correlation equation was defined and it is used for the calculation of discharges of the Korentan spring from values of water table measured in the well.

Mean daily values were calculated for the period of one hydrological year from 23 September 2003 to 31 August 2004. The lowest discharge in this interval amounted to $1 \mathrm{l} / \mathrm{s}$, the highest was 2.9 $\mathrm{m}^{3} / \mathrm{s}$, whereas the mean discharge was $0.2 \mathrm{~m}^{3} / \mathrm{s}$. The hydrogram shows typical characteristics of karst springs with high short-term flow rates and prolonged periods of medium and low waters (Fig. 3).

The main source of recharge of the karst aquifer is primary infiltration of precipitation. The precipitation data were obtained at the meteorological station Postojna, which is among all stations managed by the Environmental Agency of the Republic of Slovenia the most representative for the Korentan area. In a raingauge daily values are measured, but the station is also equipped with a rainfall recorder for continuous recording of precipitation. As the water table in the well at the Korentan spring is measured in time intervals of 15 minutes, also the amounts of precipitation were defined by the analysis of these records in the same intervals. In the upper graph of Figure 3 daily values of precipitation and discharge for the period of one hydrological year 2003/2004 are compared. Fast reactions of the Korentan spring on storm events are characteristic for the studied karst aquifer.

As various processes that take place in the air, in vegetation, and in the soil influence the actual input of water into the rock, for the further comparison daily values of effective infiltration were used instead of precipitation. They were estimated by the use of the method of soil moisture balance. In this the precipitation that reaches the ground (not intercepted by vegetation) and the snowmelt represent the source of water, and the evapotranspiration the loss of it back into the air. The relation between these receipt and consumption is affected by the hydrological properties of the soil, which

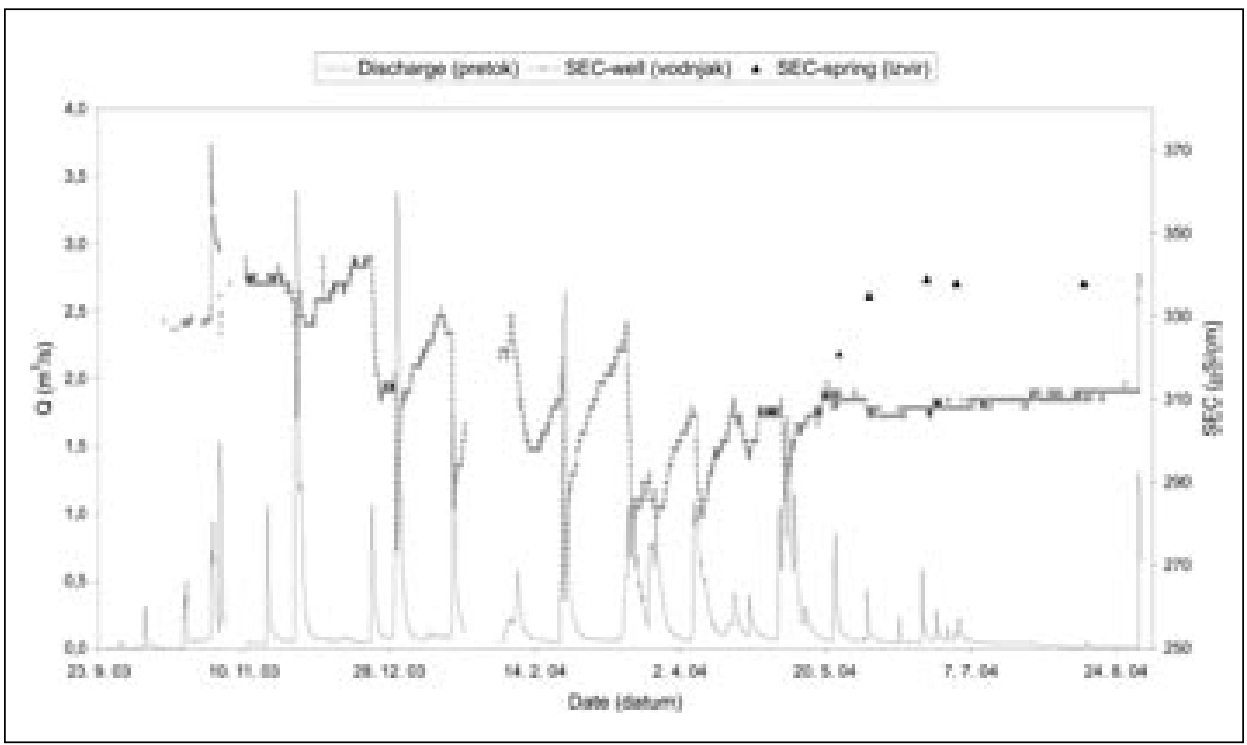

Fig. 4: Discharges and specific electrical conductivity of the Korentan spring.

Sl. 4: Pretoki in specifična električna prevodnost izvira Korentan. 
in turn determine the amount of water that may get stored in it and the amount of effective infiltration respectively. Such model was previously set in the Microsoft Excel software tool and tested for the recharge area of the Vipava spring (Petrič 2002). The same model was used for the Korentan catchment. Meteorological data (precipitation, thickness of the snowpack, air temperature, relative air humidity, wind velocity, sunshine hours) were obtained at the Postojna meteorological station,

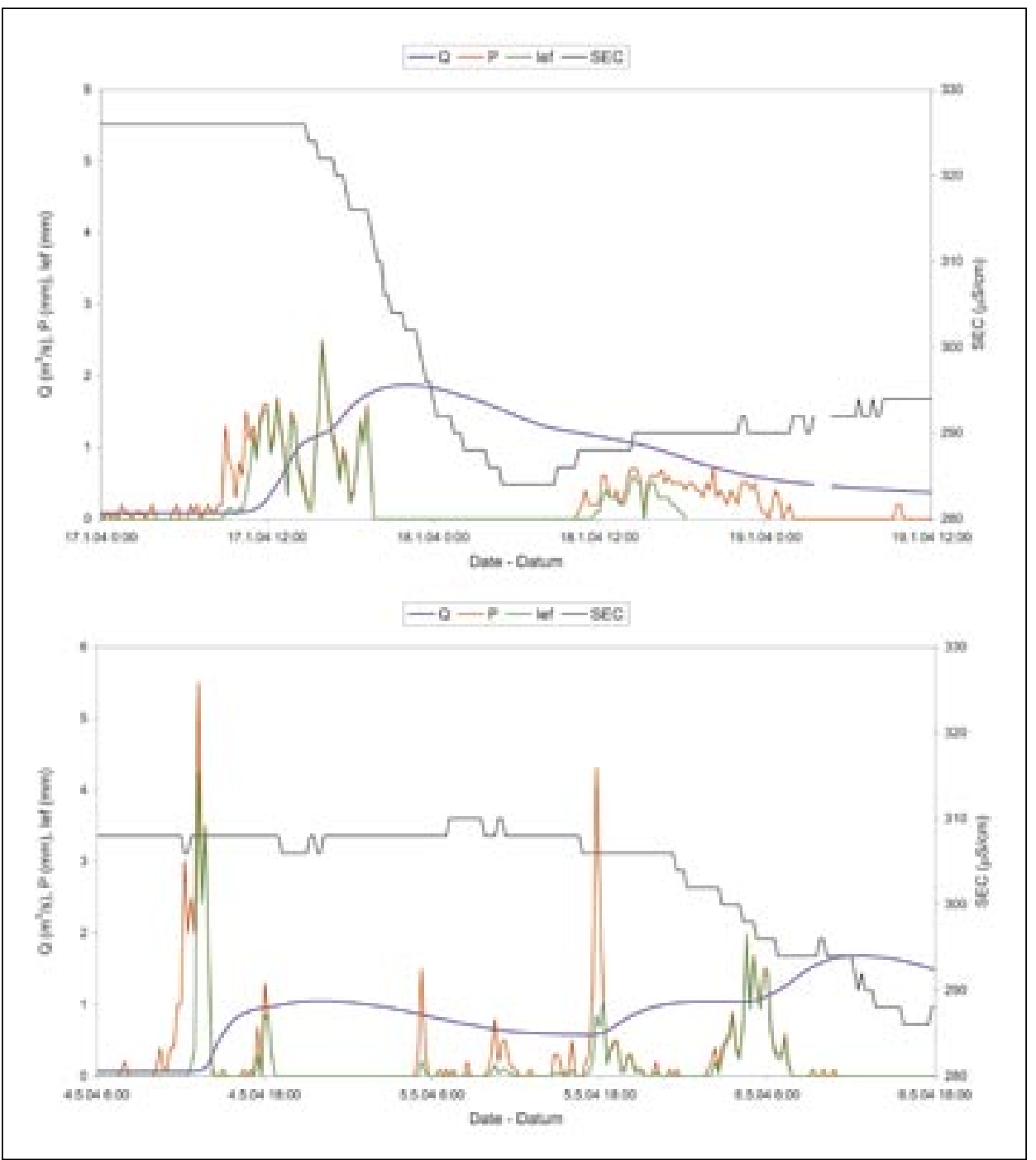

Fig. 5: Comparison of precipitation, effective infiltration, discharge, and specific electrical conductivity for two storm events.

Sl. 5: Primerjava padavin, efektivne infiltracije, pretoka in specifične električne prevodnosti za dva padavinska dogodka. 
and also data from vegetation and soil maps were used. Owing to the lack of data describing the characteristics of water storage on vegetation and in soil, these data were defined in the process of final calibration of the model. Namely, the model of soil moisture balance is based on the presumption that within the period of one hydrological year the overall effective infiltration in the total recharge area is equal to the overall discharge of the Korentan spring. In described way estimated daily values of effective infiltration are presented in the lower graph of Figure 3. The seasonal effect can be seen with the lesser share of effective infiltration during spring and summer as a consequence of the start of the exuberant vegetation growth or less intensive precipitation.

In the well at the Korentan spring also the specific electrical conductivity was measured by the ISCO YSI 600 Sonde in time intervals of 15 minutes. Results for the hydrological year 2003/2004 are presented on Figure 4. Rapid changes of discharge are followed by significant changes of conductivity, which also reflect the karst character of the Korentan spring.

Interesting phenomenon can be observed at the beginning of both hydrological years in October 2003 and September 2004 (Fig. 4). First intensive precipitation event is followed by a significant increase of the specific electrical conductivity. This can be explained by the fact that although the Korentan spring is also at these extremely low conditions still active with a discharge of several litres per second, there is no flow in the well where the probes are installed. Old water stays captured in the well and in the time without new inflow practically no changes of specific electrical conductivity are observed. In this period the same parameter was measured directly at the outflow of the Korentan

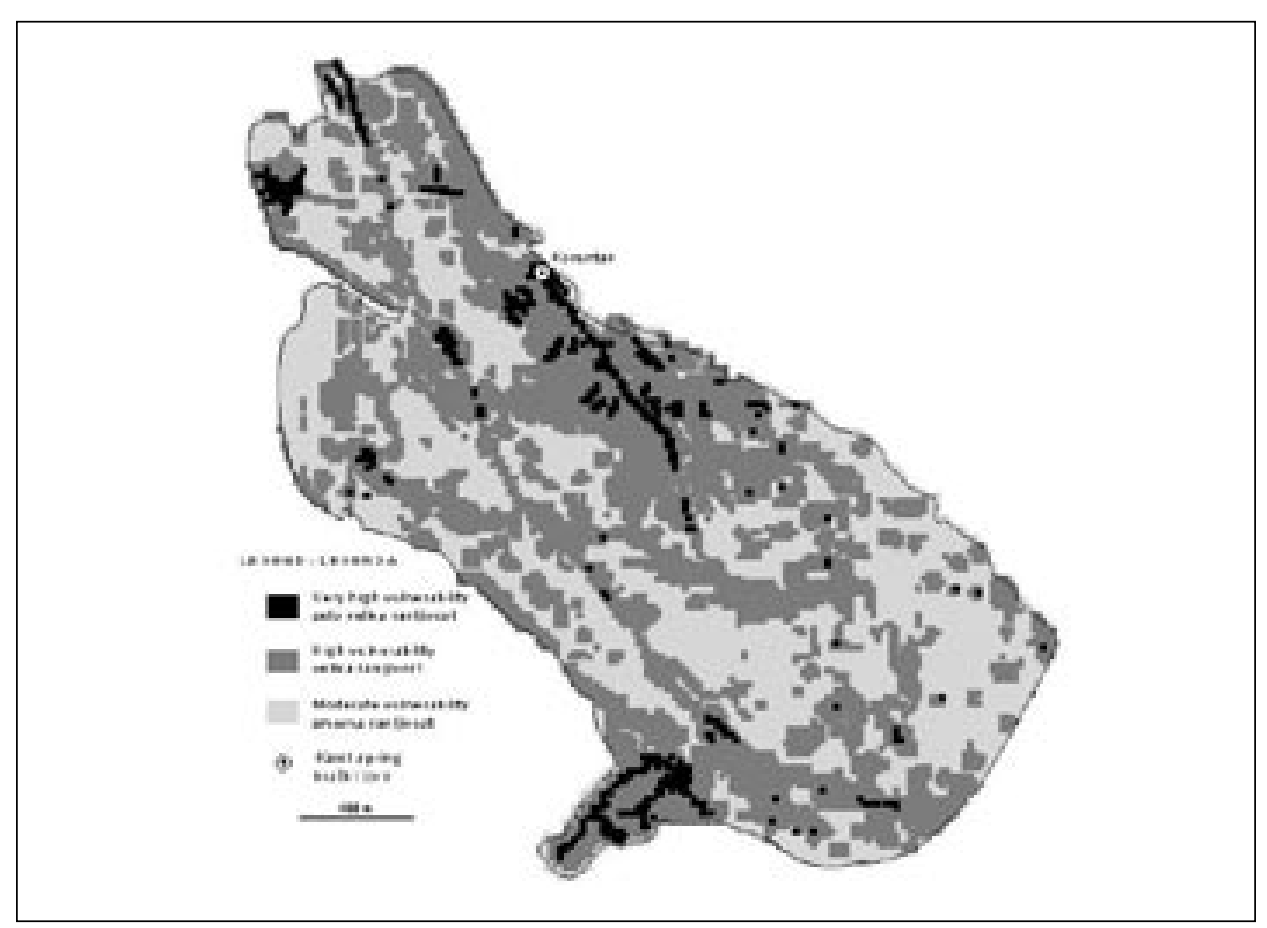

Fig.6: Vulnerability map.

Sl. 6: Karta ranljivosti. 
spring and some noticeable differences can be observed (Fig. 4). The increase of specific electrical conductivity after first intensive precipitation event can be therefore explained by the reactivation of the inflow in the well.

\section{Spring response to precipitation events}

In addition to the comparison between recharge and discharge on a daily basis, the spring response to precipitation events can be studied also in more details (Ryan \& Meiman 1996, Desmarais \& Rojstaczer 2002, Birk et al. 2004). Interesting results were obtained by superimposing the records of precipitation, discharge and specific electrical conductivity. As an example two storm events of January 2004 and May 2004 are presented on Figure 5 for a time-span of two and a half days.

For all storm events in the observation period of one hydrological year the increase of discharge starts within a short time after the precipitation. The lag can be less than one hour, and can reach up to 12 hours. Individual reactions depends on the distribution and intensity of the rainfall in the observed and preceding days, therefore the discharges were compared also with the effective infiltration. For the estimation of this parameter the above described model of soil moisture balance was used, but due to the lack of proper data the accuracy of such model is for short intervals of 15 minutes rather lower. Still some approximate estimation of the type of reaction of the spring on infiltration is possible. As it can be seen for two presented examples (Fig. 5), the longer delay in the reaction of discharge especially in summer or spring periods is due to the processes that take place in the air, in vegetation or in the soil and hinder the actual infiltration of precipitation into the rock. At times when these influences are small, the discharges of the Korentan spring start to increase with the delay of just few hours or even less after the start of precipitation.

In the January example the storm event starts around midnight at the onset of 17 January with a mild precipitation of up to $0.2 \mathrm{~mm}$, which is not sufficient to infiltrate into the karst rock. Effective infiltration begins at around 9 a.m. as a result of some more intensive rain. Less than one hour later the discharge of the Korentan spring starts to increase and reaches the maximum three hours after precipitation ceases. Already in the time of rising of the discharge approximately five hours after its start, the specific electrical conductivity begins to decrease and low hardness storm water reaches the spring. The inflow of this "new" water dominates for additional 16 hours when the increase of specific electrical conductivity commences again.

In the second example the precipitation event is composed of three relatively stronger storms. Again the effective infiltration begins with a lag of two and a half hours after the start of precipitation. The infiltrated water then stimulates the prompt increase of discharge, but the arrival of the actual recharge water at the spring is indicated by the decrease of specific electrical conductivity only after 27 hours.

Some conclusions about the characteristics of the studied karst aquifer can be made on the basis of the above described conditions. There is almost no lag between the onset of the infiltration of precipitation into the rock and the rising limb of the hydrograph. It means that the infiltrated water reaches quickly the saturated zone. This causes the rise of the water table and the consequential increase of the discharge of the spring. In this process the "new water" forces out the "old water" which was previously stored in the aquifer and has the same chemistry as the water discharging from the spring before the storm. Therefore no changes in the specific electrical conductivity are observed. Then the start of its decrease represents the first arrival of storm water at the spring. The 
time lag behind the start of the rising limb of the hydrograph is different for individual events, but with several hours or one to two days still relatively short. This indicates very fast flow and also transport of dissolved matter through the karst aquifer. Due to described conditions the vulnerability of the system is very high and an eventual pollution can spread through it very fast.

\section{VULNERABILITY MAPPING}

Obtained results about the characteristics of the karst aquifer in the recharge area of the Korentan spring were used for the vulnerability mapping. The EPIK method was applied. It is a multi-atribute weighting-rating parametric approach, which is above all used in karstic areas (Doerfliger et al. 1999). The assessment of intrinsic vulnerability was based on the rating of four parameters: development of the epikarst (E), effectiveness of the protective cover (P), infiltration conditions (I), and development of the karst network $(\mathrm{K})$. The whole recharge area was divided into elemental cells (squares with $20 \mathrm{~m}$ long sides). Throughout the area all parameters were mapped and a weighting coefficient was assigned to each of them according to their protection function. By adding protection values of four parameters a protection index was calculated for each cell. Different index values were grouped into three classes as a function of their connection with three degrees of vulnerability. In this way a map was produced which represents the spatial distribution of vulnerability.

The categories of parameter $E$ were defined based on the results of detailed structural-lithological and geomorfological mapping described in previous chapters. The most vulnerable category E1 was assigned to the areas with dolines, swallow holes, karren fields, fissured and broken zones, the category E2 to the intermediate zones of these features, and the less vulnerable E3 to the rest of the catchment.

The soil layer above the karst aquifer has a function of a protective cover. Its effectiveness depends on the characteristics and depth of soil. Basic data about these attributes were for the studied area obtained from a pedological map in a scale 1:25000 (Podatki tal Slovenije 2004). Since no significant differences in the protection capacity of individual soil types were stated, only the depth of the cover was considered in the evaluation of the parameter P. It was defined by field observation using the principle of morphological equivalence. In some control points such estimation was tested by direct measurements of soil thickness by the use of a hand auger. Since no low permeable geological formations occur below the soil, only three categories of the parameter $\mathrm{P}$ were assessed according to the soil thickness below $20 \mathrm{~cm}$ (P1), between 20 and $100 \mathrm{~cm}$ (P2), and above $100 \mathrm{~cm}$ (P3).

The infiltration conditions were characterised by the identification of zones of concentrated infiltration in swallow holes and by the identification of zones of diffuse infiltration. As a basis for this assessment topographic maps were used, but additional field mapping was carried out to verify the data. In the recharge area of the Korentan spring the Črmelice ponor and the ponor in the area of Sv. Barbara were identified as swallow holes, and therefore classified as the most vulnerable category I1. Also the banks and bad of streams recharging them were placed into the same class. For the rest of the area inside the catchment of these streams two categories were distinguished according to the slope of the ground and the type of land use. The first was calculated by the processing of DEM with a grid resolution of $25 \mathrm{~m}$ in the Golden Software Surfer 8, and the second on the basis of a vegetation map (Puncer et al. 1982), a topographic map, and field observations. Areas with ground slopes greater then $10 \%$ for arable land and greater than $25 \%$ for meadows and pastures were characterised 
as I2, and those with lower slopes as I3. In the same class I3 were classified also areas outside the stream catchment with slopes grater than $10 \%$ and $25 \%$ respectively. The rest of the study area, also with diffuse infiltration, is in the less vulnerable category I4.

Direct and indirect methods were used in order to assess the degree of development of the karst network. In the recharge area of the Korentan spring around 40 caves are registered. By field mapping also many surface karst features were defined. All these karst objects are direct indictors of well developed karst network, and this category of the parameter $\mathrm{K}$ was confirmed also by indirect methods. As described in more details in previous chapter, by parallel analysis of hydrograph and chemograph of the Korentan spring it was indicated that fast flow and transport of dissolved matter are characteristic for the studied karst aquifer. Therefore parameter K1 describing a moderate to well developed karstic network was applied for the entire catchment.

Finally, the protection index for each cell was calculated following the EPIK method. These indexes were then categorised into three vulnerability classes and on the map the areas of very high, high, and moderate vulnerability were defined (Fig. 6). The first category was assigned to the areas directly connected to swallow holes or to the areas where diffuse infiltration is due to well developed epikarst and thin soil layer effective and fast. On the other hand, only moderately vulnerable are mostly those parts of the catchment with lower ground slopes where absence of karst features indicates poorly developed epikarst zone. The rest of the catchment was classified into the intermediate zone of high vulnerability.

\section{CONCLUSIONS}

The quality of the vulnerability map strongly depends on the quality of the input data. Therefore it is important to use different hydrogeological research methods for the evaluation of parameters, which influence the vulnerability. In the applied EPIK method these are: development of the epikarst, effectiveness of the protective cover, infiltration conditions, and development of the karst network.

For the recharge area of the Korentan spring basic data about the karst aquifer were obtained by detailed structural-lithological and geomorphological mapping. Locations and characteristics of dolines, swallow holes, caves, karren fields, and fissured and broken zones were defined by field work. By interpretation of these data the stage of epikarst development and the infiltration conditions were assessed.

Additional information about the nature and functioning of observed aquifer was acquired by comparison of the time series of precipitation, discharge and specific electrical conductivity. The reaction of the Korentan spring on precipitation events is very fast. Prompt increase of discharge is a result of mobilisation of older water which was previously stored in the karst aquifer. And then already after several hours or one to two days the first arrival of the new storm water is indicated by a decrease of specific electrical conductivity. Such characteristics are typical for karst aquifers with fast groundwater flow and transport of dissolved matter, and are considered in the assessment of the development of the karst network.

Application of different types of more detailed research methods can be very useful for the assessment of the aquifer vulnerability and can improve the quality of obtained vulnerability maps. To test such advancement, further research has been planned and the next step will be an additional validation by tracing with natural and artificial tracers. 


\section{REFERENCES}

Birk, S., \& R. Liedl \& M. Sauter, 2004: Identification of localised recharge and conduit flow by combined analysis of hydraulic and physico-chemical spring responses (Urenbrunnen, SWGermany).- Journal of Hydrology, 286, 179-193, Amsterdam.

Buser, S. \& K. Grad \& M. Pleničar, 1967: Osnovna geološka karta SFRJ, list Postojna 1:100000.Zvezni geološki zavod, Beograd.

Čar, J., 1982: Geološka zgradba požiralnega obrobja Planinskega polja (Geologic Setting of the Planina Polje Ponor Area).- Acta carsologica 10, 75-105, Ljubljana.

Desmarais, K., \& S. Rojstaczer, 2002: Inferring source waters from measurements of carbonate spring response to storms.- Journal of Hydrology, 260, 118-134, Amsterdam.

Doerfliger, N. \& P.-Y. Yeannin \& F. Zwahlen, 1999: Water vulnerability assessment in karst environments: a new method of defining protection areas using a multi-atribute approch and GIS tools (EPIK method).- Environmental Geology 39 (2), 165-176.

Gospodarič, R., 1989: Prispevek k vodnogospodarskim osnovam Pivke.- Acta carsologica, 18, 2137, Ljubljana.

Gospodarič, R. \& F. Habe \& P. Habič, 1970: Orehovški kras in izvir Korentana (The karst of Orehek and the source of the Korentan).- Acta carsologica, 5, 95-108, Ljubljana.

Habič, P. \& R. Gospodarič \& J. Kogovšek, 1987: Raziskave kraških izvirov v Malnih pri Planini in zaledja vodnih virov v občini Postojna.- Tipkano poročilo, pp. 58, Arhiv IZRK ZRC SAZU Postojna.

Jurkovšek B. \& M. Toman \& B. Ogorelec \& L. Šribar \& K. Drobne \& M. Poljak \& L. Šribar, 1996: Formacijska geološka karta južnega dela Tržaško-Komenske planote, Kredne in palogenske karbonatne kamnine, 1:50 000.- GZL, p. 143, Ljubljana.

Petrič, M., 2002: Characteristics of recharge-discharge relations in karst aquifer.- Založba ZRC, pp. 154, Postojna-Ljubljana.

Placer, L., 1981: Geološka zgradba JZ Slovenije.- Geologija 24/1, 27-60, Ljubljana.

Placer, L., 1999: Prispevek k makrotektonski rajonizaciji mejnega ozemlja med Južnimi Alpami in Zunanjimi Dinaridi.- Geologija 41, 223-255, Ljubljana.

Pleničar, M., 1970: Osnovna geološka karta SFRJ 1:100000. Tolmač za list Postojna.- Zvezni geološki zavod, 1-62, Beograd.

Podatki tal Slovenije, 2004. Center za pedologijo in varstvo okolja. URL (quoted 15.1.2004): http: //www.bf.uni-lj.si/cpvo/Novo/main_PodatkiTalSlovenije.htm

Puncer, I. \& M. Zupančič \& M. Wraber, 1982: Vegetacijska karta Postojna L33-77.- SAZU, Razred za naravoslovne vede, Biološki inštitut Jovana Hadžija, p. 118, Ljubljana.

Ryan, M. \& J. Meiman, 1996: An examination of short-term variations in water quality at a karst spring in Kentucky.- Ground Water, 34, 23-30, Westerville.

Shaw, E.M., 1994: Hydrology in Practice.- Chapman \& Hall, p. 569, London.

Schulte, U., 1994: Geologische und Hydrogeologische Untersuchungen im Karst von Orehek (Slowenien).- Diplomarbeit, Universität Karlsruhe, Deutschland.

Šebela, S., 1998: Tectonic structure of Postojnska jama cave.- Založba ZRC 18, p. 112, Ljubljana. 


\section{KARTIRANJE RANLJIVOSTI V ZALEDJU IZVIRA KORENTAN, SLOVENIJA}

\section{Povzetek}

Izvir Korentan je glavni iztok iz vodonosnika Orehovškega krasa. Do leta 1972 je bil zajet za vodooskrbo Postojne, v zadnjem času pa razmišljajo, da bi ga kot rezervni vir ponovno vključili v sistem. Vzporedno se je pokazala tudi potreba po posodobitvi obstoječih strokovnih podlag za njegovo varovanje. Zato smo za zaledje izvira izdelali karto notranje ranljivosti z uporabo metode EPIK.

Orehovški kras obsega območje okrog $9 \mathrm{~km}^{2}$ (Sl. 1). Osnovne podatke o njegovi geološki zgradbi smo povzeli po obstoječi literaturi, dopolnili pa smo jih z detajlnim strukturno-litološkim kartiranjem. V tektonskem smislu je del tektonske enote Javorniško-Snežniških grud (Pleničar, 1970), po Placerju (1981, 1999) pa je del Snežniške narivne grude, ki je narinjena na Komensko narivno grudo.

Gospodarič et al. (1970) so prikazali drugačno geološko karto Orehovškega krasa, kot je prikazana na OGK list Postojna (Buser et al. 1967). Zgornjekredne nekoliko zrnate in brečaste apnence z rudisti so našli okrog prestranškega gradu, potem pa še v ozkem pasu pri Orehku ter južno od Hruševja in severno od Sajevč in Rakulika. Osrednji del grebena pa je sestavljen iz paleogenskih apnencev. To je temni apnenec liburnijske formacije s foraminiferami Rhipidionina liburnica Stache in Rhapidionina liburnica Stache ter s polži Stomatopsis sp. in Cosinia cf. Odlikujejo se po drobnozrnati strukturi, po dobro razvitih skladih, ki nekje že prehajajo v skrilavi apnenec, in po tem, da vsebujejo nekaj roženca.

Detajlno strukturno-litološko kartiranje smo opravljali v merilu 1:5.000 po metodi Čarja (1982). Določili smo tektonske deformacije povezane z gubanji in narivanji, kot so narivi in antiklinale (Sl. 2). Omejili smo tektonske in litološke stike med eocenskim flišem in karbonatnimi kamninami. Interpretacije glede narivnih in/ali litoloških kontaktov med flišem in karbonati so različne (Gospodarič et al. 1979, Pleničar 1970, Schulte 1994). Vsi avtorji pa so si enotni, da je Z in JZ meja med karbonati in flišem narivna, kar pomeni, da so karbonati narinjeni na eocenski fliš med Hruševjem, Rakulikom in Kočami.

Naša interpretacija SV roba Orehovškega krasa se bolj ujema z Gospodaričem et al. (1970), kot pa z narivnimi mejami med različnimi litološkimi členi (Schulte 1994). Kontakt med eocenskim flišem in zgornje krednim apnencem je SZ od Korentana prelomen. Ta prelom sledimo na izviru Korentana, potem pa ga lahko sledimo vse do brezna Pivka jama. Predel SZ od Orehka predstavlja erozijsko mejo med flišem in zgornje krednim apnencem in prelomno mejo med zgornje krednim in apnencem liburnijske formacije. Kraški teren med Orehkom in Rakulikom je naguban v dve skoraj vzporedni antiklinali in premrežen s prelomi dinarskih smeri (SZ-JV) ter z razpoklinskimi in porušenimi conami dinarskih in prečno-dinarskih smeri.

Apnenec je dobro zakrasel z značilnimi površinskimi in podzemnimi kraškimi oblikami. Gostota vrtač, ki so večinoma razporejene vzdolž glavnih tektonskih con, je približno $60 \mathrm{na} \mathrm{km}^{2}$. Registriranih je tudi okrog 40 jam. Na južnem obrobju površinski tok Črmelic ponika na stiku fliša z apnencem in dodatno napaja kraški vodonosnik. Ta se prazni skozi izvir Korentan, kjer vode prihajajo na površje skozi številne razpoke v 50 m široki izvirni coni.

Ena izmed teh razpok je bila razširjena v vodnjak, iz katerega so črpali vodo za vodooskrbo. V njem smo v juniju 2003 vzpostavili merilno postajo, ki omogoča merjenje pretokov in specifične električne prevodnosti v 15-minutnih intervalih. Z obdelavo zapisov z ombrografa na bližnji meteorološki postaji Postojna smo za enake intervale pridobili tudi podatke o padavinah. Po metodi 
bilance vode v tleh smo ocenili še dnevne vrednosti efektivne infiltracije. Na sliki 3 je za hidrološko leto 2003/2004 prikazana primerjava pretokov s padavinami in efektivno infiltracijo, na sliki 4 pa s specifično električno prevodnostjo vode na izviru.

$S$ primerjavo zapisov padavin, pretokov in specifične električne prevodnosti smo analizirali tudi odziv izvira na posamezne nevihte (Sl. 5). Ugotovili smo, da izvir praktično brez zakasnitve reagira na infiltracijo padavin $\mathrm{v}$ kamnino s povečanjem pretoka. To pomeni, da infiltrirana voda hitro doseže zasičeno cono vodonosnika. Posledica je dvig nivoja podzemne vode in posledično povečanje pretoka izvira. V tem procesu »nova« voda iztisne »staro« vodo, ki je bila že predhodno uskladiščena v vodonosniku in ima enak kemizem kot voda, ki je iztekala skozi izvir pred nevihto. Zato se specifična električna prevodnost v tej fazi ne spreminja. Šele začetek padanja njenih vrednosti napove prvi prihod nove, nevihtne vode do izvira. Zaostanek za začetkom naraščanja pretoka je za posamezne dogodke različen, vendar z zamudo od nekaj ur do enega ali dveh dni relativno kratek. To kaže na zelo hiter tok in tudi transport raztopljenih snovi skozi kraški vodonosnik, s tem pa tudi na zelo veliko ranljivost sistema.

Ugotovljene značilnosti smo uporabili pri izdelavi karte notranje ranljivosti po metodi EPIK, ki temelji na primerjavi štirih parametrov: razvitosti epikrasa (E), učinkovitosti varovalnega pokrova (P), pogojev infiltracije (I) in razvitosti kraške mreže (K).Pri ovrednotenju parametra razvitosti epikrasa smo upoštevali rezultate detajlnega strukturno-litološkega in geomorfološkega kartiranja. Kot glavni kriterij za učinkovitost varovalnega pokrova smo postavili debelino prsti, ki smo jo ocenili na osnovi pedološke karte, $\mathrm{z}$ upoštevanjem principa morfološke ekvivalentnosti in dodatnim terenskim merjenjem debelin na izbranih točkah z ročnim vrtalnim svedrom. $Z$ uporabo topografskih kart in rezultatov geomorfološkega kartiranja smo ovrednotili pogoje infiltracije, z vzporedno analizo hidravličnih in fizikalno-kemičnih odzivov na padavinske dogodke pa še razvitost kraške mreže. Z ustrezno obdelavo podatkov smo opredelili območja z zelo veliko, veliko in zmerno ranljivostjo (S1. 6). 